\title{
The Superstable Marker as an Indicator of Categorial Weakness?
}

\section{Antje Dammel \& Damaris Nübling}

\begin{abstract}
In this article we examine and "exapt" Wurzel's concept of superstable markers in an innovative manner. We develop an extended view of superstability through a critical discussion of Wurzel's original definition and the status of marker-superstability versus allomorphy in Natural Wurzel's original definition and the status of marker-superstability versus allomorphy in Natural Morphology: As we understand it, superstability is - above and beyond a step towards uniform-
ity - mainly a symptom for the weakening of the category affected (cf. 1., 2. and 4.). This view is exemplified in four short case studies on superstability in different grammatical categories of four Germanic languages: genitive case in Mainland Scandinavian and English (3.1), plural formation in Dutch (3.2), second person singular ending -st in German (3.3), and ablaut generalisation in Luxembourgish (3.4).
\end{abstract}

\section{Introduction and definition}

In Naturalness Theory the existence of so-called superstable markers (überstabile Marker) plays an important role. ${ }^{1}$ Superstable markers such as the genitive ending $-s$ in English and Mainland Scandinavian spread from their original 'class to other inflectional classes without changing or destroying the inflectional class systems. The term stems from Wurzel (1987) and (2001) and is defined as follows:

Marker können sich auch innerhalb des Flexionssystems ausbreiten, ohne daß ein Klassenübertritt erfolgt. Die Flexion der Wörter einer gegebenen Flexionsklasse wird nach dem Vorbild anderer Flexionsklassen verändert, ohne daß diese dabei ibre Identität als eigene Klasse verliert. Genauer: Eine Flexionsklasse übernimmt aus anderen Flexionsklassen den Marker für eine Kategorie bzw. ein Kategorienbündel. Es handelt sich dabei immer um Marker stabiler Klassen, die gleichzeitig noch in weiteren (stabilen oder instabilen) Klassen vorkommen, und deshalb über einen höheren Stabilitätsgrad verfiigen als die Flexion der jeweiligen Klasse insgesamt. Aufgrund dieser hohen Stabilität tendieren sie dazu, aus der stabilen Klasse gleichsam auszuscheren und sich schneller und umfassender im Flexionssystem auszubreiten als diese. Dabei ergibt sich eine Art von 'Lawineneffekt': Jede Ausbreitung eines Markers auf eine neue Flexionsklasse erhöht seinen Stabilitätsgrad weiter. Auf diese Weise kann ein einzelner Marker schließlich alle Flexionsklassen erfassen, wobei diese ihre Selbständigkeit jedoch nicht einbüßen. Wir wollen solche Marker [...] als überstabile

Folia Linguistica XL/1-2

$0165-4004 / 05 / 40-97 \$ 2$.

(C) Mouton de Gruyter, Berlin

Societas Linguistica Europaea 
Marker bezeichnen. Die Verbreitung von überstabilen Markern vollzieht sich nich nur zwischen Komplementärklassen. Sie hat damit einen grundlegend anderen Status als der Klassenwechsel. (Wurzel $22001: 139$ )

Instead of a translation, we quote the corresponding definition in Wurzel (1987: 82-83):

But categorial markers, as is well known, can also spread in the inflectional system without the word concerned changing its membership in an inflectional class, i.e. single markers are taken from one class to the other. This is always the case for markers of stable inflectional classes which also occur in non-stable inflectional clases. exhibit a exhibit a highe degree of stability than the stable inflectional class as a whole and can be characterized as superstable markers. Superstable markers show a trend towards 'diverging' from the inflectional paradigm and independently spreading more quickly and comprehensively than the inflectional classes to which they belong. [...]

Cases where superstable markers are attached to inflectional forms already having the respective categorial characteristics illustrate that the spreading of single markers follows non-proportional analogy and does not involve the basic lexical form, cf. die Junge- $n$ 'the boys'> die Junge-n-s in analogy to die Mädel-s etc.

The spreading of superstable markers in inflectional systems results in a kind of 'avalanche effect': Every spreading of a marker to a new inflectional class further increases its degree of stability, which improves the preconditions for its transfer to still further inflectional classes, etc.

As an example, Wurzel (2001) and (1987) cites the development of the genitive $-s$ in Swedish, which originally only occurred in the singular of the masculine and neutral $a$-class (fisk-s 'fish-gen.', skip-s 'ship-gen.'). First it spread into the masculine $i$-class as well as into the athematic class, where it replaced the old endings (rätt-ar > rätt-s 'dish-gen.', fot-ar > fot-s 'foot-gen.'). From there it moved into the class of kinship terms, and afterwards into all the remaining declension classes, including feminines. Finally it extended from singular number into the plural (kvinn-or-s 'woman-Pl-gen.'). Although Wurzel emphasizes that superstable markers do not lead to a merger of inflectional classes, it must be claimed that they cause at least a partial merger by diminishing the differences between two classes.

Thus, contrary to Wurzel's definition, we do not consider it necessary to constrain the term to cases where inflectional class differences in paradigmatic slots other than that of the superstable marker are retained. Both situations superstability with and without retaining inflectional classes - do not differ fundamentally, but only in the degree of deflection (cf. also the case studies in 3.1 and 3.2). In spite of his strict definition, Wurzel (e.g. ${ }^{2} 2001$ : 180) implicitly assumes the same in his discussion of superstable $-s$ in the genitive and plural of English nouns.

Wurzel adds the strength of superstable markers in deflection as a further criterion: Superstable markers resist the elimination or reduction of morphology the longest.
In the following we will argue that the term "superstable marker" evokes false expectations. In our opinion, superstability marks the beginning of the end of morphological expression. Thus, superstable markers indicate quite the reverse concerning the category they express, i.e. they only indicate the weakness of the respective category. This will be shown by several examples: (a) the genitive $-s$ in English and Mainland Scandinavian; (b) the plural formation in Dutch; (c) the spreading of the personal ending $-s t\left(2^{\text {nd }}\right.$ sing.) in the verbal system of German; (d) a rather interesting case in Luxembourgish where the loss of the whole preterite was preceded by a complete generalisation of one ablaut class.

Allomorphs must be considered the counterpart of superstable markers, all of which symbolize the same meaning but have different forms, ranging from purely phonologically-conditioned and formally often (but not always) rather similar forms (e.g. the plural allomorphs in English) right through to completely different forms such as the many plural allomorphs in German, whose distribution depends on different factors (Neef 2000a,b). Our second goal therefore is to demonstrate that allomorphy indicates highly relevant information and reflects the strength of the respective category.

This approach is aimed directly at inflectional languages, of which inflectional classes and allomorphy are defining properties. We do not apply the idea 'uniformity means categorial weakness' to agglutinating languages, of which uniformity is a decisive criterion (Kilani-Schoch \& Dressler 2005: 113-116, Dressler \& Kilani-Schoch 2005).

\section{Superstable markers versus allomorphs}

In the framework of Naturalness Theory superstable markers constitute a step towards the second important, universally valid naturalness principle: uniformity. Uniformity refers to a one-to-one-relation between function and form. This is also regarded as an aim in morphological change. This principle could also be termed the "anti-allomorphy principle" because it leads to the elimination of heteromorphous conditions. If one of different allomorphs starts replacing others, more uniformity is created. The existence of superstable markers therefore indicates the effectiveness of the uniformity principle. If the superstable marker only occurs in semantically marked subsets of categories, constructional iconicity, the most important Naturalness principle, is also fulfilled. The third principle, transparency, represents the mirror image of uniformity, meaning that one form (morph) only corresponds to one function (morpheme). Furthermore, this principle also includes morphotactic (formal) and morphosemantic transparency (fully compositional meaning). For further principles, cf. Dressler (2000).

Superstable markers as a step towards uniformity should be omnipresent if uniformity really were an important ideal in morphology. Yet, there are many examples of rich allomorphy which do not show any signs of reduction, and 
even the creation of or increase in allomorphy can be observed. In order to "explain" the many instances of allomorphy, Wurzel (2001) developed systemdependent (language-specific) naturalness, an expansion of system-independen Naturalness Theory. This modification often has been criticized because it allows contradictions to the universally valid concept.

Only rarely has the precise function of the underlying category been investigated or even questioned. The markedness concept is only concerned with intracategorial relations such as singular versus plural within the number category. One failure of Naturalness Theory is its neglect of the intercategorial dimension: Which categories are more important than others? Which deserve to be expressed morphologically and which ones syntactically? Which categories should be realized on special word classes? If such questions are asked, it becomes obvious that number is a completely different sort of information than case, gender, and definiteness. Here, the distinction between inherent (e.g number) and contextual morphology (e.g. case) in the sense of Booij (1996) becomes crucial. The number category concerns the number of objects and is expected to be expressed on the respective words denoting objects themselves, whereas case expresses the semantic role of the denoted object(s) in the whole sentence. Thus, case works on the sentence level and number on the word level. This sort of diagrammatic iconicity has been best described by the relevance principle of Bybee (1985, 1994 etc.). The knowledge of this concept is taken for granted. The relevance aspect could be regarded as an important supplement to Naturalness Theory. Although Bybee does not explicitely correlate a high amount of allomorphy with a high degree of categorial relevance, we strongly emphasize such a correlation which is sketched in Figure 1.

Thus, our claim is: A high amount of allomorphy reflects a highly relevant category in the sense of Bybee $(1985,1994)$ as well as a high degree of inflectional strength in morphology. Languages with a high degree of allomorphy are highly-inflected languages and are not threatened by deffection. Superstable markers, on the contrary, indicate the reverse: a small degree of relevance and/or the beginning of morphological simplification which can (but need not) precede deflection. Deflection is always preceded by morphological simplification but not every simplification must lead to deflection.

Thus, English still preserves number inflection on the noun but it is well known that English, together with Afrikaans, belongs to the most analytic Germanic languages. Number is much more relevant for the concrete noun (often denoting countable objects) than case. After the separation of the case/number portmanteau inherited from Germanic, which, apart from Icelandic and Faroese, occurred in all Germanic languages, the less relevant case category was expressed by function words (such as prepositions) and/or eventually by syntactic means (e.g. by the pre-/postverbal position). The more relevant number category,
Figure 1: The correlation of morphological abundance and relevance

superstable markers

allomorphs

low degree of relevance

low degree of fusion

between stem and affix

(concatenative)

sign of inflectional weakness

(sometimes even of deflection)

examples:

noun: case

verb: person, number

adj.: case, number

high degree of relevance

high degree of fusion between stem and affix

(stem alternations)

sign of inflectional strength

number

$T A M$

gradation

however, continued as the only morphologically expressed category on the noun while the other nominal elements (determiner, adjectives) completely jettisoned their number inflections. These facts on the syntactic level correlate perfectly with the reduction of plural allomorphs located on the paradigmatic level. The emergence of the sole (one) plural morpheme $\{\mathrm{s}\}$ (with three phonologically conditioned allomorphs [s], [z], and [Iz]) presupposes an earlier emergence of a superstable marker (the $s$-plural can be traced back to the former masculine strong $a$-class). Considering the highly deflectional state of English, even the rather uniform expression of number underlines the high relevance of this category. German, on the other hand, remained a highly-inflected language. After the separation of case and number, which began as early as Old High German (around 800 a.d.) with the neutral $i z / a z$-class (Wurzel 1992a), case and number underwent extremely divergent developments: While case reduced its degree of allomorphy to the extent that it is no longer expressed morphologically (as, e.g., in the feminine), number's "stock" rose to new heights, a development which is termed Numerusprofilierung (number strengthening) in German linguistics. Modern German has more plural allomorphs than Middle High German, i.e. the amount of allomorphy even increased, and, following Bybee's claims, is expressed closest to the lexical stem, often even inside the stem by stem alternations (umlaut). These cases of increased allomorphy are, however, not the main topic of this paper (for this topic cf. Nübling 2000 and 2001). In the following, we want to document and discuss the emergence of superstable markers (and their subsequent development), i.e., we only provide examples for the leftmost end of the above scale. 


\section{Superstable markers: Four case studie}

3.1 Genitive case in Mainland Scandinavian and English

As already mentioned in the introduction, Wurzel provides the paradigmatic expansion of genitive $-s$ in Swedish as a classic example of a superstable marker (cf. 22001: 140f.). The development of the $s$-genitive fits Wurzel's definition nicely because it shows a gradual spread from its original domain, the genitive singular of masculine and neuter (i) $a$-stems, crossing borders to non-competing classes (as early as Old Swedish to the masc. $r$-stem kinship terms, $u$-stems), later to other masc. and neuter classes, then to feminines (majority in 15th century) and finally to plural number and to pronouns. This process stretches from Runic Swedish (800) to Early Modern Swedish (-1732) and is most dynamic in later Middle Swedish (1375-1526). At the end of it, the $s$-genitive reigns in all inflection classes in all genders and in both numbers of nouns and pronouns. For a careful and fine-grained analysis of the $s$-genitive's expansion see Norde (1997: 116-127), which is the source of the chronology used here. Similar developments hold for English, Danish and Norwegian. All of these languages show a strong tendency towards deflection.

Let us now look further to the point where Wurzel stops in order to show that the expansion of the $s$-genitive is only the shiny side of the coin, the flip side being the complete loss of the morphological category case. What Wurzel does not take into account is the change of domain for the $s$-genitive. Its spread correlates with its reanalysis from a case marker controlled on the morphological level towards a possessive phrase-marking clitic assigned on the syntactic level (cf. e.g. Norde 1997 for Swedish, Carstairs 1987 for English and Danish, and Johannessen 1989 for Norwegian).

In the following sections some pieces of synchronic evidence shall be introduced, supplied with some important diachronic milestones of the development (for detailed discussion see the references cited before). First, the $s$-genitive is no longer assigned on the noun itself, but rather attached to the right end of the nominal phrase (NP). The marking domain changed from word level to phrase level. The process is totally insensitive to word class, cf. the examples in (1) This loss of selectivity is a main criterion in separating less selective clitics such as the $s$-genitive, which can attach to virtually all word classes, from strictly selective affixes such as plural allomorphs, which are constrained to the noun (cf. Zwicky \& Pullum 1983: 503f.). Thus, if we don't want to assume that all the word classes clitizised by $-s$ in (1) inflect for genitive case, we must admit that $s$-genitive is no more a marker of morphological case.

(1) Lack of selectivity in phrase marking $s$-genitive (English examples from Plank 1992: 27f.)

a) the man opposite me's funny hat (personal pronoun)
b) the man who is drunk's hat
(adjective)
c) in a month or two's time
(numeral)
d) the man who is talking's hat
e) the man over there's hat
(verb)
f) the man I talked to's theory
(adverb)
(preposition)
g) somebody else's hat
(particle)

Second, compared to affixes, the $s$-genitive lacks morphophonological fusion with its hosts. It never alters the phonological shape of the host it is attached to. This criterion, too, separates it as a clitic from affixes (cf. Zwicky \& Pullum 1983: 503, 505). The latter often modify the stem that they are bound to, which is a sign of a higher degree of fusion and leads to idiosyncrasies. Compared with fossilized lexical genitives after the preposition till (2a) or the linking $-s$ in compounds (2b), the Swedish $s$-genitives never trigger shortening or devoicing (2c). In English the enclitic genitive 's does not lead to voicing of the stem final consonant, while the affixal plural $-s$ does (3). In English, lack of fusion is also reflected orthographically in separating genitive $<$ 's $>$ through an apostrophe.

(2) Lack of influence on the stem of clitic $s$-genitive (Swedish examples from Norde 1997: 69)
a) till skogs
b) skogsbruk
/skuks/ 'to the forest' /skuksbrük/
'forestry'

(3) wife $[\mathrm{f}]-$ wife's [f] (+ genitive $-s)$ versus wives $[\mathrm{v}](+$ plural $-s)$

i (English examples from Plank 1985)

With respect to diachronic evidence for the reanalysis from a categorial case marker to an enclitic phrase marker, Norde (1997: 227) states that, first, in Swedish only adnominal genitives adopted secondary $-s$. It never spread to lexical genitives (governed by prepositions or verbs). It is true that the latter disappeared at the end of the Old Swedish period, but by then phrase-marking genitives already occurred. Thus, Norde concludes "that the expansion of $-s$ was not simply an instance of paradigm shift" (227). Second, the trend away from word-marking case also figures in the loss of internal genitive marking on definite nouns. In Old Swedish (1225-1375) the genitive was marked twice, both next to the stem before and after the definiteness suffix. The internal genitive flexives were gradually abolished (4). (4) OSw fisk-s-in-s
fish-gen.-def.-gen.
$\rightarrow \mathrm{NSw}[$ fisk-en]-s,
[fisken i hinken]s fena fish-def.-gen. "the fish in the bucket's fin"

Third, in the development of the fixed prenominal position of modifiers in today's Swedish, genitive $-s$ was the only marker which moved to the new position. 
Although other genitive endings were still available, only the ending which had been reanalyzed as a phrase marker and thereby lost morphological status was movable (cf. Norde 1997: 229).

The relative chronology of reanalysis and spread has been the subject of controversial discussion. The traditional account is that spread leading to uniformity was a prerequisite for the reanalysis as a phrase marker. The English data seem to confirm this (see e.g. Carstairs 1987 after Jespersen, but cf. Norde 1997: 225). But the Swedish data show the opposite chronology: Reanalysis as a phrase marker here precedes the massive spread of $-s$ towards uniformity (cf. Norde 1997: 225f.). Group genitives already occurred when case marking still showed allomorphy. According to Norde (1997: 223f.) the genitive $-s$ won out by having the best preconditions for reanalysis. It was most salient, never in danger of phonological reduction and unique as a case marker, showing no paradigmatic homonymy. ${ }^{2}$ The other Swedish genitive allomorphs $-a(r)$ and $-a$, which were reduced in several dialects, did not develop into phrase markers, but followed other less successful strategies when concordial case agreement was given up (e.g. genitive marking on adjectives).

But the differences in chronology do not weaken the main point: The seemingly superstable expansion of genitive $-s$ actually reflects the ultimate weakening and final loss of the morphological category case. It is striking that the expansion of superstable genitive $-s$ succeeded only in languages with general deflection. In German, on the contrary, where case is marked by dependent and head constituents of the NP in interplay, $-s$ has spread only moderately. This genitive case study provides evidence that superstable markers are signals indicating the weakness of a morphological category, and can thus be symptoms of deflection.

\subsection{Plural formation in Dutch}

Although English nouns no longer exhibit any inflectional classes (every noun forms the genitive and the plural by adding $\{\mathrm{s}\})$, Wurzel (2001: 180) sees this as the effect of superstable markers, in this case of both endings (case and number). This shows that superstable markers can lead to uniformity, i.e. that they may ultimately cause the merger of different inflectional classes (remainders of the other classes, such as oxen, children, mice, are considered as exceptions). Thus, English abolished its nominal inflectional class system (ibd., p. 109). The dative and accusative cases and gender were completely eliminated. The distribution of the three allomorphs [s], [z], and [Iz] is purely phonologically conditioned as well as phonologically explainable (in the sense of Neef 2000a: 463) and is thus controlled by the stem. All these facts testify to the weakness of the underlying categories. In earlier stages of English it was the plural ending which dominated the stem by causing umlaut (foot/feet, man/men, mouse/mice etc.) or by voicing the final consonant (wife/wives, calf/calves, hou[s]e/hou[z]es etc.). This direction of influence has been reversed and thus iconically reflects categorial weakening. This is also confirmed by the absence of any further plural marking in the whole NP.

German, on the contrary, has nine different native plural allomorphs, some of which even occur twice, both as an ending and as a stem alternation: Kuh/ Küh-e 'cow(s)', Haus/Häus-er 'house(s)'. The assignment principles are rather complicated (often even idiosyncratic) and strongly depend on one of the three preserved genders. This paradigmatic abundance is reflected on the syntactic level: case, gender, and number are expressed repeatedly in the NP, especially on the article.

Dutch is rather interesting because it holds an intermediate position. Although it still preserves two genders (neuter and common gender), the distribution of the two productive plural allomorphs $-s$ and -en is only conditioned by stress position and the final sound of the stem (although they are not formally derivable from one another). Thus, a clear downgrading of the assignment principles has taken place. Umlaut has been eliminated (apart from stad/steden 'town(s)') but there are still some quantitative alternations left, such as $d[a] g /$ $d$ [a:Jgen 'day(s)'. The remaining NP only kept a few remnants of number and gender marking. The definite article, for instance, symbolizes gender only in the singular (het: neuter, de: common gender). In the plural, gender is neutralized, and the article is homonymous with the singular of the common gender, de. The completely uniform indefinite article een has no gender distinction. As a possible consequence, every noun (similar to English) has to form a clear plural, i.e. there are no zero plurals (contrary to German) except for semantic reasons (Booij 2002).

Unlike English, Dutch chose the ending -en of the weak declension as its superstable marker. Later, the $s$-plural emerged and replaced many en-plurals, a process which is still ongoing today. If there are alternative plurals such as appelen and appels 'apples', the $s$-plural is the innovative one. Thus, one superstable marker was replaced by another. The actual distribution is rather clear: " $s$ after an unstressed syllable, -en after a stressed syllable" (Booij 2002: 24). Polysyllabic words, especially those ending in [ə] + nasal or liquid, take $-s$, monosyllabic ones (or polysyllabic ones ending with a stressed syllable) take -en in order to produce trochees: dag/dag-en 'day(s)', but vogel/vogel-s 'bird(s)'.

The flexive $-e n$ is the older one and spread from the weak declension (originally masculines and feminines) into the strong classes of all genders. This is partly demonstrated in Tables 1 and 2 (below). In some areas of the Netherlands, $n$ after [o] is not pronounced and therefore put in brackets.

As a further step, the weak endings spread on a huge scale to the strong classes with $e$-plurals. In the early stages strong case endings still existed in the 
singular. They were later jettisoned. With the elimination of the case system, it was only the plural which defined an inflectional class. But since superstable markers do not cause a shift of inflectional classes, the question arises of whether a superstable plural marker, which is already in the process of spreading, becomes obsolete only because some system-defining properties changed. We would argue strongly against this because the process in itself remains the same (cf. Chapter 1). Table 2 illustrates the further development of the $e$-marker. The strong neuters originally lacked a plural suffix (woort/woort 'word(s)'). This explains why the superstable marker quickly spread into this class (Table 3).

The same holds for the strong feminine $i$-class: Middle Dutch $\mathrm{cracht}$ cracht-e > Modern Dutch kracht/kracht-en 'power'. As already mentioned, the stem internal modifications (umlaut) which all occurred in this class, were eliminated (in Dutch only short $a$ was umlauted to $e$ ). Here, Dutch chose the diametrically opposed path from the one taken in German, which used umlaut as a systematic means of plural marking by morphologizing it.

In Dutch, there remains an unproductive group of roughly 15 nouns with a double plural in -eren (going back to the Germanic neutral iz/az-class): kind/kind-eren 'child', kalf/kalv-eren 'calf', ei/ei-eren 'egg', volk/volk-eren 'people', rad/rad-eren 'wheel', with $d$-epenthesis: hoen/hoend-eren 'chicken', been/beend-eren 'leg'. Their former plural suffix -er was no longer interpreted as a plural morpheme, but instead of replacing it with -en, it was extended by the superstable marker. This form of so called double inflection (Doppelflexion) is, according to Wurzel (2001: 140), a good indicator for a superstable marker (he provides the double genitive marking in German (des) Buchstabe-n-s 'letter-gen.-gen.').

As early as Middle Dutch another plural marker arose whose origin is disputed: $-s$ (cf. Philippa 1981, 1982, Marynissen 2001). There was no Dutch declension class which produced this suffix but it is assumed that Flemish neighbour dialects provided this new marker. It competed with -en and launched a career as a new superstable marker. Following the historical grammars, this plural began with agent nouns originally forming their plural with $-e$, then with $-e n$, and finally with $-s$ : Sing. ridder - Plur. ridd(e)r-e $>$ ridder-en $>$ ridder-s. Initially it only occurred in the nominative plural, then later in the whole plural. It then attached to non-agent words ending in -er (keiser-s), then to further nouns denoting persons (broeder-s), and finally to many other bisyllabic nouns (including all diminutives). The advantage of the s-plural is its brevity and its acoustic salience. It should be added that the aforementioned alternations of stem vowel quantity only occur with plurals in -en (d[a]g/d[a:]gen 'day(s)'). Plurals in $-s$ always correlate with an absolutely stable and uniform stem - a further indicator of their simplicity: They only consist of an additive marker without any influence on the stem.
Table 1: The profiling of -en as plural marker in Middle Dutch (exemplified by a weak masc., 'name')

\begin{tabular}{|c|c|c|c|c|}
\hline & Middle Dutch & remarks & Modern Dutch & remarks \\
\hline $\begin{array}{l}\text { Sing. } \\
N \\
G \\
D \\
A\end{array}$ & $\begin{array}{l}\text { name }>\text { name } \\
\text { namen }>\text { name_ } \\
\text { namen }>\text { name_ } \\
\text { namen }>\text { name }\end{array}$ & $\begin{array}{l}\text { the case endings }-n \\
\text { are eliminated in the } \\
\text { singular, }\end{array}$ & $\begin{array}{l}\text { naam_[na:m] } \\
\text { naam_ } \\
\text { naam_- } \\
\text { naam_ }\end{array}$ & $\begin{array}{l}e \text {-apocope (15th cent) } \\
\text { strengthens number } \\
\text { contrast }\end{array}$ \\
\hline $\begin{array}{l}\text { Plur. } \\
\text { N } \\
\text { G } \\
\text { D } \\
\text { A }\end{array}$ & $\begin{array}{l}\text { namen }>\text { namen } \\
\text { namen }>\text { namen } \\
\text { namen }>\text { namen } \\
\text { namen }>\text { namen }\end{array}$ & $\begin{array}{l}\text { but not in the plural } \\
\text { ( } n \text {-reduction is mor- } \\
\text { phologically condi- } \\
\text { tioned) }\end{array}$ & \begin{tabular}{|l|} 
nam-en [na:mə(n)] \\
nam-en \\
nam-en \\
nam-en
\end{tabular} & $\begin{array}{l}\text { analogical spreading/ } \\
\text { extension of the plu- } \\
\text { ral -en }\end{array}$ \\
\hline
\end{tabular}

Table 2: The superstable marker -en replacing the strong ending -e (exemplified by dach 'day')

\begin{tabular}{|c|c|c|c|}
\hline & Middle Dutch & Modern Dutch & remarks \\
\hline $\begin{array}{l}\text { Sing. } \\
\text { N } \\
\text { G } \\
D \\
A\end{array}$ & $\begin{array}{l}\text { dach } \\
\text { dagh-es } \\
\text { dagh-e } \\
\text { dach }\end{array}$ & $\begin{array}{l}\text { dag [da } \chi] \\
\text { dag } \\
\text { dag } \\
\text { dag }\end{array}$ & $\begin{array}{l}\text { Elimination of case } \\
\text { endings }\end{array}$ \\
\hline $\begin{array}{l}\text { Plur. } \\
N \\
G \\
D \\
\text { A }\end{array}$ & $\begin{array}{l}\text { dagh-e }>\text { dagh-en } \\
\text { dagh-e }>\text { dagh-en } \\
\text { dagh-e- } n>\text { dagh-en } \\
\text { dagh-e }>\text { dagh-en }\end{array}$ & $\begin{array}{l}\text { dag-en [da:yə(n)] } \\
\text { dag-en } \\
\text { dag-en } \\
\text { dag-en } \\
\end{array}$ & $\begin{array}{l}\text { In Middle Dutch, the } \\
\text { strong plural ending }-e \\
\text { is replaced by the weak } \\
\text { ending -en }\end{array}$ \\
\hline
\end{tabular}

Table 3: Extension of the superstable marker -en to the zero marked neuters (exemplified by woort 'word')

\begin{tabular}{|l|l|l|l|}
\hline & Middle Dutch & Modern Dutch & remarks \\
\hline Sing. & & woord [vo:rt] & Elimination of case \\
N & woort & woord & endings \\
G & woord $(e) s$ & woord & \\
D & woorde & woord & \\
A & woort & woord-en [vo:rde(n)] & Extension of superstable \\
\hline Plur. & woort $>$ woord-en & marker in Middle Dutch \\
N & woord-e > woord-en & woord-en & \\
G & woord-en $>$ woord-en & woord-en & woord-en \\
A & woort $>$ woord-en & word-en & \\
\hline
\end{tabular}


Today both suffixes are productive but $-s$ is stronger because it continues to replace -en. Afrikaans clearly confirms this tendency by having much more plurals with $-s$ than Dutch. Here, many monosyllabic words ending in a nasal or liquid can be suffixed by $-s$, i.e. the formalization of the distribution has been extended, meaning that the assignment principles only depend on forma factors. As a further simplification, Afrikaans completely eliminated its gender system (although even in Dutch, gender no longer affects plural formation). Thus, the connection between superstable markers and categorial weakening becomes obvious.

\subsection{Second person singular ending -st in German}

The third case concerns the verbal system of German ${ }^{3}$. In present German, the personal ending of the 2nd sing. -st is one of the few examples of a real uniform marker. This was different in earlier times. In Old High German, there were three different allomorphs, $-s t,-\varnothing$, and $-t$. In the preterite of strong verbs the third ablaut stage was used and suffixed by $-i$, which caused umlaut on the stem vowel. Here, one example from the third ablaut class, werfan 'throw', is provided:

\begin{tabular}{|c|c|c|c|c|}
\hline $\begin{array}{l}\mathrm{OHG} \\
\text { ablaut stage }\end{array}$ & $\begin{array}{l}\text { werf- - } \\
\text { I }\end{array}$ & $\begin{array}{l}\text { warf } \quad- \\
\text { II }\end{array}$ & $\begin{array}{l}\text { wurf- } \\
\text { III }\end{array}$ & $\begin{array}{l}\text { worf- } \\
\text { IV }\end{array}$ \\
\hline tion of: & $\begin{array}{l}\text { inf. } \\
\text { present } \\
\text { subj.I }\end{array}$ & 1.+3.sg.pret. & $\begin{array}{l}\text { 2.sg.pret. } \\
\text { 1.-3.pl.pret. } \\
\text { subj.II }\end{array}$ & past part. \\
\hline
\end{tabular}

The $2^{\text {nd }}$ sg.pret. was OHG wurf-i, which developed regularly to MHG würf-e. Later the second ablaut stage warf- was taken as new base of this form. More important is the fact that the ending -st of the present tense of all strong verbs as well as of all tenses of the weak verbs became superstable and replaced the former ending $-e$ (beginning as early as $12^{\text {th }} / 13^{\text {th }}$ century). Interestingly, the superstable marker -st was established before the analogical stem change from wïrf- to warf- took place (according to warf in the $1^{\text {st }}$ and $3^{\text {rd }}$ sg.pret.):

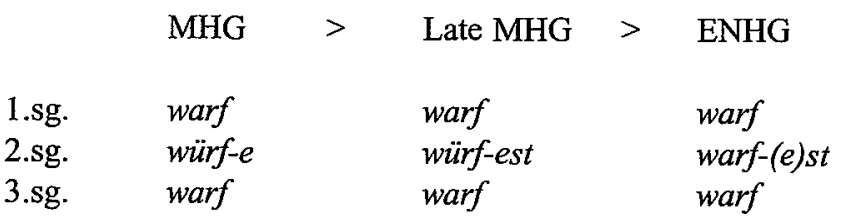

This clearly shows that concatenative suffixes can be transferred more easily than fused stem morphemes.

The third allomorph, $-t$, belonged to the special class of preterite-presents: MHG $d u$ kan-t 'you can', du darf-t 'you are allowed', $d u$ wil-t 'you want' etc. were only replaced later by the superstable marker $-s t$; this crossing of the inflectional class borders is most decisive for superstable markers. Depending on the respective token frequency, this change took place in different stages: $d u$ kan-st as early as MHG, du darf-st in the $15^{\text {th }}$ century, and $d u$ wil (l) -st only in the $17^{\text {th }} / 18^{\text {th }}$ centuries. The more frequent the verb form, the longer it resists analogical leveling. This is a clear indicator that superstable markers first replace "weak" forms (with little lexical strength). After this change, -st was completely uniform. Altogether, it must be said that in German language history a clear weakening of the person and number category occurred. For instance, many person/number syncretisms emerged which were not only phonologically but also morphologically conditioned. On the other hand, mood and especially tense underwent an extraordinary strengthening by increased allomorphy, often affecting the lexical stem. For instance, the different vowel (and consonant) alternations increased from OHG to NHG from roughly 10 to more than 40 types (for further detail cf. Nübling \& Dammel 2004). The spreading of the described superstable marker strongly supports this tendency of categorial person/number weakening.

\subsection{Ablaut generalisation in Luxembourgish}

The Luxembourgish verbal system provides examples for the expansion of superstable markers in both situations, the weakening of a less relevant category and category weakening under deflection, which shall only be outlined here. As in German, a superstable second person marker $-s$ spread to all classes in all tenses. The diachrony of this spread has not yet been investigated in detail, but seems to be similar to German outlined in 3.3.

Considering superstability as an indicator of category weakening, Luxembourgish was subject to preterite loss and kept only roughly twenty token-frequent preterite forms, mainly of strong and irregular verbs. Before the loss of the whole preterite category, however, the strong preterite forms generalized only one of the many ablaut vowels, namely -ou-, stemming from the $2^{\text {nd }}$ Germanic ablaut class, e.g. Lux. blouf'remained', koum 'came', gouf 'gave', gesouch 'saw', goung 'went' (cf. Werner 1990). This subclass of strong verbs was not the most type-frequent one (lurking behind I and III) and should not have been very stable in terms of the Naturalness Theory framework. Nevertheless, this vowel has been completely generalized. This development is a case of weakening of only one category value. The highly relevant tense category as a whole, however, keeps a high amount of modificatory allomorphy in present forms and perfect participles, e.g. goen - gaang 'go - gone', bleiwen - gebliwwen 'remain - remained'. A similar modificatory marker spread also occurs in Dutch strong verbs (cf. Hempen 1988). Thus, there really are examples for superstable modificatory markers which confirm the weakening of the respective category. Such cases are not as frequent as 
affixal superstability but they do occur nevertheless. We therefore think that the concept of superstability should be extended to modificatory markers.

\section{Conclusions}

The loss of allomorphy and the corresponding tendency towards uniformity that the spread of superstable markers leads to, is no sign of increasing Morphological Naturalness, but rather a symptom of category weakening. The higher cognitive costs to memorize a high degree of allomorphy are only worthwhile for very strong and relevant categories. In categories of minor relevance or in languages subject to deflection, superstable markers spread, yielding lower memorizing costs. This also sheds new light on the status of uniformity as one of the most important Naturalness principles. If uniformity is linked to morphological weakness, it should be asked whether this principle should be regarded as a really desirable aim of morphological change: The abolition of morphology cannot be the aim of morphology.

In agglutinating languages, however, uniformity is a rather stable feature Therefore, it is striking that inflectional languages do not tend toward more uniform structures. This could be part of what Dressler $(2000,2003)$ terms type-adequacy.

As a desideratum, we regard a more comprehensive definition of the term superstable marker which abolishes the condition that inflection classes must be retained. Furthermore, the concept could be defined as gradual, yielding degrees of superstability. This would allow us to discuss marker spread between minor, irregular classes in terms of superstability, too. In addition, superstability should be applicable to spreading markers that belong to types of exponence other than affixation (as shown in 3.4). More case studies of marker spread in different non-related language families are necessary. Last but not least, the flip side of the coin, the preservation and even increase of allomorphy, should be analyzed in detail and related to the questions which have been sketched in this article.

\section{Notes}

1 Wurzel (2001:209) also uses the term "over-stable marker".

2 However, paradigmatic homonymy didn't disturb the development in English towards superstable genitive and plural markers (both in $-s$ ).

3 German is usually subdivided in the following periods:

Old High German - OHG (750-1050)

Middle High German - MHG (1050-1350)

Early New High German - ENHG (1350-1650)

New High German - NHG

\section{Address of the authors:}

Damaris Nübling, Antje Dammel

Johannes Gutenberg-Universität Mainz

FB 05, Deutsches Institut

55099 Mainz

Germany

E-Mail: nuebling@uni-mainz.de

dammel@uni-mainz.de

\section{References}

Booij, Geert. 1996. "Inherent versus contextual inflection and the split morphology hypothesis." Geert Booij \& J. van Marle (eds.), Yearbook of Morphology 1995, 1-16.

Booij, Geert. 2002. The Morphology of Dutch. Oxford: University Press.

Bybe Joan 1985. Morphology: A study of the relation between meaning and form Amsterdam \& Philadelphia: Benjamins.

Bybee, Joan. 1994. "Morphological Universals and Change." In: R. E. Asher (ed.), The Encyclopedia of Language and Linguistics 5. Oxford: Pergamon Press, 2557-2562.

Carstairs, Andrew. 1987. "Diachronic evidence for the affix-clitic distinction." In: Anna Giacolone Ramat, Onofrio Carruba \& Giuliano Bernini (eds.), Papers from the 7th international conference on historical linguistics. Amsterdam \& Philadelphia: Benjamins (Current Issues in Linguistic Theory 48), 151-162.

Dressler, Wolfgang. 1985. "On the predictiveness of Natural Morphology." Journal of Linguistics 21, 321-337.

Dressler, Wolfgang. 1988. „Zur Bedeutung der Sprachtypologie in der Natürlichen Morphologie.“ In: Jörn Albrecht, Harald Thun \& Jens Lüdtke (eds.), Energeia und Ergon: Sprachliche Variation - Sprachgeschichte - Sprachtypologie: Studia in honorem Eugenio Coseriu, vol. 3. Tübingen: Narr, 199-209.

Pressler, Wolfgang. 2000. "Naturalness." In: Geert E. Booij, Christian Lehmann, \& Joachim Mugdan (eds.), Morphology: An International Handbook on Inflection and Word-Formation. Vol. 1. Berlin \& New York: De Gruyter (Handbooks of Linguistics and Communication tion. Vol. 1. Berlin \& New York:

Dressler, Wolfgang. 2003. "Naturalness and Morphological Change." In: Brian Joseph, Richard Dressler, Wolfgang. 2003. "Naturalness and Morphological Change." In: Brian Joseph, R
Janda (eds.), The Handbook of Historical Linguistics. Oxford: Blackwell, 461-471.

Dressler, Wolfgang, Willi Mayerthaler, Oswald Panagl \& Wolfgang Ullrich Wurzel. 1987. Leitmotifs in Natural Morphology. Amsterdam \& Philadelphia: Benjamins (Studies in Language Companion Series 10).

Dressler, Wolfgang \& Marianne Kilani-Schoch. 2005. "Iconicité dans la flexion du verbe français." In: Gertraud Fenk-Oczlon \& Chr. Winkler (eds.), Sprache und Natürlichkeit. Gedenkband für Willi Mayerthaler. Tübingen: Narr, 57-74.

Hempen, Ute. 1988. Die starken Verben im Deutschen und Niederländischen: Diachrone Morphologie. Tübingen: Niemeyer (Linguistische Arbeiten 214).

Johannessen, Janne Bondi. 1989. “Klitika - en avgrensning.” Norsk lingvistisk tidsskrift 2.1989, 117-147.

Kilani-Schoch, Marianne \& Wolfgang Dressler. 2005. Morphologie naturelle et flexion du verbe français. Tübingen: Narr.

Marynissen Ann 2001. Die Flexion des Substantivs in der mittelniederländischen Urkundensprache des 13. Jahrhunderts." In: Kurt Gärtner (ed.), Skripta, Schreiblandschaften und Standardisierungstendenzen: Urkundensprache im Grenzbereich von Germania und 
Romania im 13. und 14. Jahrhundert. Trier: Kliomedia (Trierer Historische Forschungen 47), 659-672.

Mayerthaler, Willi. 1981. Morphologische Natürlichkeit. Wiesbaden: Akademische VerlagsGesellschaft Athenaion (Linguistische Forschungen 28).

Mayerthaler, Willi. 1987. "System-independent morphological naturalness". In: Dressler et al. (eds.), 25-28.

Neef, Martin. 2000a. "Phonologische Konditionierung." In: Geert E. Booij, Christian Lehmann, \& Joachim Mugdan (eds.), Morphology: An International Handbook on Inflection and Word-Formation. Vol. 1. Berlin \& New York: De Gruyter (Handbooks of Linguistics and Communication Science [HSK] 17.1), 463-473.

Neef, Martin. 2000b. "Morphologische und syntaktische Konditionierung." In: Geert E. Booij, Christian Lehmann, \& Joachim Mugdan (eds.), Morphology: An International Handbook on Inflection and Word-Formation. Vol. 1. Berlin \& New York: De Gruyter (Handbooks of Linguistics and Communication Science [HSK] 17.1), 473-484.

Norde, Muriel. 1997. The history of the genitive in Swedish: A case study in degrammaticalization. Amsterdam: Vakgroep Skandinavische taal- en letterkunde.

Nübling, Damaris. 2000. Prinzipien der Irregularisierung: Eine kontrastive Untersuchung zu zehn Verben in zehn germanischen Sprachen. Tübingen: Niemeyer (Linguistische Arbeiten 415)

Nübling, Damaris. 2001. "The Development of 'junk'. Irregularization Strategies of have and say in the Germanic Languages." In: Geert E. Booij, Jaap van Marle (eds.), Yearbook of Morphology 1999. Boston, Mass.: Kluwer Academic Publishers, 53-74.

Nübling, Damaris \& Antje Dammel. 2004. „Relevanzgesteuerter morphologischer Umbau im Frühneuhochdeutschen". Beiträge zur Geschichte der deutschen Sprache und Literatur $126.2,177-207$.

Philippa, Marlies. 1981. "De meervoudsvorming op -s in het Nederlands vóór 1300." Tijdschrift voor Ndl. Taal- en Letterkunde 97, 81-103.

Philippa, Marlies. 1982. "Problematiek rond het s-meervoud: een diachroon overzicht." De niuewe taalgids $75,407-417$.

Plank, Frans. 1985. "The interpretation and development of form alternations conditioned across word boundaries: the case of Wife's, Wives and Wives'." In: Roger Eaton, Olga Fischer, Willem F. Koopman \& Frederike van der Leek (eds.), Papers from the 4th international conference on English historical linguistics. Amsterdam/Philadelphia: Benjamins (Current Issues in Linguistic Theory 41), 205-233.

Plank, Frans. 1992. From cases to adpositions. In: Pantaleo, Nicola (ed.), Aspects of English diachronic linguistics. Fasano: Schena (Biblioteca della Ricerca: Cultura Straniera 48), 19-61.

Werner, Otmar. 1990. „Die starken Präterita im Luxemburgischen: Ideale Analogie oder vergeblicher Rettungsversuch?" German Life and Letters 43.2, 182-190.

Wurzel, Wolfgang. 1987. "System-dependent morphological naturalness in inflection." In: Dressler et al. (eds.), 59-96.

Wurzel, Wolfgang. 1988. „Zur Erklärbarkeit sprachlichen Wandels“. Zeitschrift für Phonetik, Sprachwissenschaft und Kommunikationsforschung 41.4, 188-210.

Wurzel, Wolfgang. 1990. "The mechanisms of inflection: lexicon representations, rules, and irregularities." In: Wolfgang Dressler, Hans Luschützky, Oskar Pfeiffer \& John Rennison (eds.), Contemporary Morphology. Berlin/New York: De Gruyter (Trends in Linguistics 49), 203-216.

Wurzel, Wolfgang. 1992a. „Morphologische Reanalysen in der Geschichte der deutschen Substantivflexion." Folia Linguistica Historica 13.1-2, 279-307.
Wurzel, Wolfgang. 1992b. "The Structuralist Heritage in Natural Morphology." In: Hans-Heinrich Lieb (ed.), Prospects for a New Structuralism. Amsterdam \& Philadelphia: Benjamins (Current issues in linguistic theory 96), 225-241.

Wurzel, Wolfgang. 1994. “Grammatisch initiierter Wandel.” In: Benedikt Jeßing (ed.), Sprachdynamik: Auf dem Wege zu einer Typologie sprachlichen Wandels in 8 Bänden, vol. 1. Bochum: Brockmeyer.

Wurzel, Wolfgang. 1998. "On markedness." Theoretical Linguistics 24, 53-71.

Wurzel, Wolfgang. 2000. "Flexionsparadigma, Flexionsformen und Markiertheitsabbau." Papiere zur Linguistik 62/63, 75-87.

Wurzel, Wolfgang. 2001. Flexionsmorphologie und Natürlichkeit. $2^{\text {nd }}$ edition. Berlin: AkademieVerlag.

Zwicky, Arnold M. \& Geoffrey M. Pullum. 1983. "Cliticization vs inflection: English n't." Language 59.3, 502-513. 